\title{
Optimasi Proses Hidrolisis Vinasse Sebagai Bahan Baku Resin Polimer yang Ramah Lingkungan
}

\author{
Lestari Hetalesi Saputri \\ Program Studi Teknik Kimia, Politeknik LPP, Yogyakarta \\ email: lestari_h@politeknik-lpp.ac.id atau titatekim@gmail.con
}

\begin{abstract}
Vinasse contains some amine, carboxyl and hydroxyl groups in its organic acids. These groups when being combined with other materials can be synthesized into a raw material of coating material. This research aims to break vinasse chain by hydrolysis into amino acids. Hydrolysis is carried out at $110{ }^{\circ} \mathrm{C}$ with a residence time of 60-150 minutes (with 30-minute intervals). In addition, the rasio between the volume of vinasse and $\mathrm{HCl}$ is 1: 1, 1:2, 1:3 and 1:4. Then the material from the hydrolysis are analyzed their groups. Quantitative analysis has been conducted to determine the composition of vinasse that will be added in the next polymerization processing. The result showed that the optimum conditions of hydrolysis process is at 2 hours and volume $\mathrm{HCl}$ with the ratio of 1: 3. FTIR analysis indicated the presence of carboxyl and amines groups on hydrolyzate. The long term goal of this research is the use of vinasse as a coating material derived from biomaterials, as well as renewable materials. It could be expected that hydrolysis under acidic conditions can be an initial step to a coating material with vinasse as a raw material base.
\end{abstract}

Keywords: vinasse, polymer resin, hydrolysis, coating material

\section{Pendahuluan}

Resin sintetik seperti phenolic resin, epoxy resin ataupun perpaduan dari keduanya (phenolic-epoxy resin) adalah salah satu contoh polymer resin yang telah lama digunakan sebagai material coating, baik untuk coating furniture, circuit boards maupun untuk coating logam. Hanya saja, resin-resin sintetik umumnya masih mempunyai beberapa kekurangan, antara lain bahan bakunya yang terbatas, bersifat racun, tahan lama dan diperburuk dengan sifatnya yang sukar terdegradasi. Oleh karena itu, maka penelitian-penelitian baru untuk memproduksi polimer resin yang lebih ramah lingkungan sangat diperlukan. Vinasse adalah bahan baku utama yang diharapkan dapat digunakan sebagai bahan coating material.

Pada penelitian ini, bahan baku utama yang akan digunakan adalah vinasse. Vinasse adalah hasil samping atau limbah cair yang dihasilkan dari proses pembuatan etanol pada industri pengolahan gula [1]. Beberapa kajian untuk memanfaatan vinasse telah dilakukan seperti dihidrolisis dan dilanjutkan dengan fermentasi untuk menghasilkan bioteanol [2]. Vinasse juga telah diproses untuk menghasilkan biohydrogen melalui codigestion dengan air limbah pengolahan jagung [3], selain itu juga dimanfaatkan untuk biogas [4]. Namun selain potensi seperti yang telah dipelajari tersebut, vinasse sebenarnya memiliki potensi untuk menjadi coating material karena kandungan material yang dimilikinya.

Pertimbangan pemilihan vinasse karena bahan ini mengandung beberapa asam amino yang kaya akan gugus-gugus utama yaitu amino, hidroksil dan karboksil dalam jumlah yang tidak sama. Adanya ketiga gugus ini memberikan peluang yang besar dalam pembentukan degradable coating material yang lebih ramah terhadap lingkungan. Terlebih lagi, vinasse memiliki sifat sebagai flexibilizer di dalam resin. Keberadaan bahan ini dapat menaikkan sifat mekanis dari suatu coating material, misalnya sifat kekuatan tarik, keuletan dan sebagainya. Selain itu pula, karena merupakan limbah, vinasse bersifat lebih ekonomis dibandingkan bahan lainnya yang juga sama-sama dapat dimanfaatkan sebagai bahan baku coating material. Sifat ekonomisnya secara tidak langsung dapat mengurangi biaya produksi [5]. Sementara itu, untuk perbaikan sifat mekanis lainnya, dapat dilakukan dengan mereaksikan gugus-gugus tersebut dengan senyawa-senyawa lain yang bersifat plasticizers, pengeras dan sebagainya. Sintesisnya dapat membentuk ikatan peptida seperti halnya pada protein dan juga gugus ester. Semakin besar perbandingan mol antara ketiga gugus tersebut, maka peluang terjadinya rantai cabang akan semakin besar dan hal ini secara tidak langsung akan berpengaruh pada peningkatan sifat mekanis dari produk polimer yang dihasilkan.

Akan tetapi, ada beberapa tahapan awal yang perlu dilakukan sebelum memproduksi polimer resin dari bahan ini, yaitu mencari tahu perbandingan mol gugus amina, hidroksil dan karboksil yang terdapat dalam 
vinasse. Penentuan perbandingan ini diperlukan untuk menentukan komposisi bahan-bahan yang akan ditambahkan untuk pembuatan polymer resin vinasse. Penentuan hanya dapat dilakukan bila asam-asam organik termasuk asam-asam amino yang terdapat dalam vinasse berupa asam organik bebas. Salah satu cara pemisahan atau pemecahan yang dapat dilakukan yaitu melalui proses hidrolisis. Proses hidrolisis bertujuan untuk menguraikan vinasse menjadi monomer-monomer asam karboksilat bebas. Diharapkan melalui proses hidrolisis, asam-asam ini bisa dihasilkan dalam jumlah maksimal dan nantinya pada saat proses polimerisasinya kembali, gugus-gugus tambahan dari monomer lain dapat berada merata di setiap monomermonomer asam organik tersebut. Pemerataan gugus akan menyebabkan peningkatan sifat mekanis dari material polimer. Alasan lain dari pemilihan bahan ini karena vinasse mudah terdegradasi, mempunyai sifat adhesif yang baik serta sangat cocok sebagai pelapis dan matriks biokomposit. Selain itu, bahan ini juga bersifat renewable.

\section{Metodologi}

Bahan penelitian antara lain vinasse, $\mathrm{HCl}, \mathrm{NaOH}, \mathrm{K}_{2} \mathrm{SO}_{4}, \mathrm{CuSO}_{4}, \mathrm{H}_{2} \mathrm{SO} 4, \mathrm{H}_{3} \mathrm{BO}_{3}$, reagen asetilasi (Asam Asetat Anhidrida dan Piridin), alkohol, aquadest, inidkator PP, $\mathrm{H}_{2} \mathrm{C}_{2} \mathrm{O}_{4} \cdot 2 \mathrm{H}_{2} \mathrm{O}$ dan formalin. Sementara alatalat penelitian yang digunakan adalah timbangan digital, termometer, magnetik stirer, corong, cawan arloji, pengaduk kaca, erlemeyer, statip, klem, buret, labu ukur, gelas ukur, pipet volume, ball pump, pemanas listrik, labu kjeldahl, almari asam, pipet tetes, alat distilasi, $\mathrm{pH}$ meter, bunsen, condensor, oven, gelas beker dan FTIR.

Proses hidrolisis dilakukan dengan cara: Vinasse disaring terlebih dahulu untuk memisahkan kotorankotoran yang kemungkinan terkandung didalamnya. Lalu vinasse beserta larutan $\mathrm{HCl} 6 \mathrm{~N}$ pada perbandingan volume tertentu $(1: 1,1: 2,1: 3$ dan 1:4) dimasukkan ke dalam erlemeyer. Campuran kedua bahan tersebut direfluks dengan variasi waktu hidrolisis mulai dari 30 menit sampai 150 menit dengan interval 30 menit. Pada proses ini dilakukan pemanasan dengan suhu $110^{\circ} \mathrm{C}$. Setelah proses pencampuran, larutan didinginkan lalu dipisahkan antara filtrat dan endapannya dengan menggunakan kertas saring. Endapan dan filtrat yang dihasilkan kemudian dikeringkan dalam oven pada suhu $100{ }^{\circ} \mathrm{C}$ dan dianalisa untuk mengetahui kadar protein, jumlah gugus hidroksil, karboksil dan aminanya.

Karakterisasi dilakukan melalui analisis gugus $\mathrm{COOH}$, analisis gugus $\mathrm{OH}$, analisis amina dengan metode kjedahl dan formol, dan analisis gugus fungsi. Analisis gugus $\mathrm{COOH}$ dilakukan pada bahan hidrolisat vinasse melalui proses titrasi dengan $\mathrm{NaOH}$ alkoholik $0,1 \mathrm{~N}$. Analisis gugus $\mathrm{OH}$ dilakukan melalui proses asetilasi menggunakan reagen asam asetat anhidrida dalam pelarut piridin. Analisis gugus fungsi dilakukan terhadap sampel yang berupa bubuk dengan menggunakan alat FTIR (FourierTransform Infra Red) merk Shimadzu. Analisis gugus amina dengan menggunakan 2 metode yaitu kjedahl dan formol. Analisis kjedahl dilakukan pada sampel yang berupa cairan yaitu sample vinasse, hidrolisat filtrat 1,5 jam dan $2 \mathrm{jam}$. Sementara analisis formol dilakukan pada semua sampel baik sebelum dan sesudah proses hidrolisis.

\section{Hasil dan Pembahasan}

Proses hidrolisis dilakukan dalam suasana asam dengan bantuan $\mathrm{HCl}$ dan tidak dilakukan dalam suasana basa. Asam pada reaksi ini bukan berfungsi sebagai katalis, tetapi sebagai reaktan dan harus digunakan dengan molar 1:1 atau bahkan berlebih. Reaksi hidrolisis berlangsung secara irreversible dan diawali dengan terprotonasinya gugus Oksigen karbonil. Pada reaksi hidrolisis dengan asam, karbon karbonil diserang oleh $\mathrm{H}_{2} \mathrm{O}$ sehingga terjadi serah terima proton dan terjadi pelepasan suatu amina. Amina kemudian bereaksi dengan $\mathrm{H}^{+}$hingga menghasilkan suatu garam amina. Senyawa $\mathrm{H}_{2} \mathrm{~N}^{+} \mathrm{R}$ ' yang dihasilkan merupakan suatu ion dan tidak dapat menyerang gugus karbonil [6]. Hasil dari hidrolisis yaitu berupa endapan dan filtrat. Kedua hasil ini kemudian dianalisis untuk mengetahui banyaknya gugus karboksil, hidroksil dan aminanya. Diduga asam karboksilat yang dihasilkan adalah dalam bentuk endapan, namun ada kemungkinan juga asam karboksilat yang dihasilkan terikut di dalam filtrat. Seperti yang dikemukakan oleh Parnaudeu dkk [7], bahwa tidak semua asam hasil hidrolisis akan berada dalam fase padatan, karena sebagian akan tetap berada dalam fase cairnya. Oleh karena itulah, pengujian gugus pada kedua zat ini sekaligus dimaksudkan untuk membandingkan banyaknya asam dan jenis asam yang terdapat pada kedua zat (endapan dan filtrat hasil hidrolisis) melalui pengecekan gugus fungsi. Asam organik yang dianalisis bukan hanya berupa asam karboksilat yang memiliki gugus hidroksil $(\mathrm{OH})$ tetapi juga termasuk asam-asam amino dengan gugus fungsi amina. Pertimbangan kemungkinan kandungan-kandungan asam amino yang disebutkan pada penelitian ini merujuk pada hasil penelitian D'Mello [8]. D'Mello [8] menyebutkan sedikitnya ada 17 asam amino yang terdapat di dalam vinasse, antara lain: Aspartic Acid, Threonine, Serine, Glutamic, Prolina, Glycine, Alanine, Cysteine, Valine, Methionine, Isoleucine, Leucine, Tyrosine, Phenylalanine, Histidine, Lysine dan Arginine. 
Analisis $\mathrm{COOH}$ untuk variasi perbandingan volume $\mathrm{HCl}$ dilakukan dalam waktu 2 jam, sedangkan untuk variabel waktu hidrolisis, perbandingan volume $\mathrm{HCl}$ dibuat tetap yaitu sebesar 1:3. Gambar 1 memperlihatkan bahwa semakin banyak volume $\mathrm{HCl}$ yang digunakan pada proses hidrolisis, maka gugus $\mathrm{COOH}$ yang dihasilkan akan semakin banyak. Beragamnya konsentrasi $\mathrm{COOH}$ yang didapatkan dari hasil hidrolisis dapat menunjukkan bahwa telah terjadi pemutusan ikatan pada karbohidrat, gula dan protein membentuk asam-asam organik seperti asam-asam amino dan asam-asam hidroksi karboksilat. Pada perbandingan volume 1:3, COOH yang dihasilkan mencapai titik optimumnya dengan nilai sebesar 6,8056 mgek/gram. Asam-asam organik yang terdapat dalam endapan ini diperkirakan merupakan asam-asam organik dengan berat molekul besar atau asam-asam organik dengan struktur siklis yang memiliki tingkat reaktivitas lebih rendah daripada asam-asam organik alifatik. Sementara terjadinya penurunan pada angka perbandingan 1:4 kemungkinan disebabkan akibat terjadinya reaksi antara proton asam dari $\mathrm{HCl}$ dengan asam organik bebas pada vinasse dengan struktur rantai lurus (alifatik).



Gambar 1. Grafik konsentrasi $\mathrm{COOH}$ hidrolisat pada berbagai variasi perbandingan volume $\mathrm{HCl}$.

Sementara itu, untuk hasil COOH pada variasi waktu hidrolisis dapat dilihat pada Gambar 2. Gambar 2 menunjukkan bahwa semakin lama waktu hidrolisis, maka tidak menjamin asam karboksilat yang dihasilkan akan semakin banyak. Waktu hidrolisis optimum pada endapan hidrolisat vinasse terjadi pada waktu 2 jam. Setelah waktu optimum ini, terjadi pengurangan konsentrasi COOH. Sementara pada hidrolisat filtrat, konsentrasi $\mathrm{COOH}$ menunjukkan kecenderungan terjadinya penurunan dengan semakin lamanya waktu hidrolisis. Dengan lamanya waktu hidrolisis, maka kecepatan reaksi pembentukan asam-asam organik kemungkinan akan lebih mengarah kepada pembentukan asam-asam organik BM besar seperti asam Tyrosine, Arginine, Phenylalanine, Histidine dan sebagainya yang merupakan asam-asam pembentuk protein dalam vinasse.



Gambar 2. Konsentrasi $\mathrm{COOH}$ hidrolisat pada berbagai variasi perbandingan waktu hidrolisis.

Analisis gugus amina pada penelitian ini menggunakan 2 metode yaitu metode analisis formol dan kjedahl. Hasil perhitungan dari kedua metode ini berupa $\% \mathrm{~N}$. Kadar N nantinya dapat digunakan untuk memperkirakan banyaknya gugus amina (konsentrasi amina dalam satuan mgek/gram) dalam sample vinasse dan hasil hidrolisisnya. Dari hasil analisis kedua metode terdapat sedikit perbedaan hasil, namun memiliki kecenderungan yang hampir sama. Berikut adalah hasil analisis \% N dengan Metode Kjedahl:

Tabel 1. Hasil analisis \% dengan metode kjedahl.

\begin{tabular}{cccc}
\hline No. & Sampel & \% N & \% Protein \\
\hline 1 & Vinasse & 0,088 & 0,552 \\
2 & Filtrat $1: 3(2$ jam $)$ & 0,018 & 0,111 \\
3 & Filtrat $1: 3(1,5$ jam $)$ & 0,0177 & 0,109 \\
\hline
\end{tabular}


Tabel 1. menunjukkan adanya penurunan $\% \mathrm{~N}$ pada filtrat hasil hidrolisis bila dibandingkan dengan sebelum hidrolisis. Penurunan kemungkinan besar disebabkan karena terbentuknya garam ammonium klorida akibat proses hidrolisis. Penggunaan $\mathrm{HCl}$ dalam proses hidrolisis menyebabkan alkil (R) pada rantai protein harus bersaing dengan anion klorida $\left(\mathrm{Cl}^{-}\right)$dari $\mathrm{HCl}$ dalam mengikat gugus amina yang terikat pada ikatan peptida. Akibatnya senyawa-senyawa amina yang dihasilkan menjadi berkurang. Sementara itu, hasil analisis kadar N dengan metode Formol dapat dilihat pada Gambar 3 dan Gambar 4.

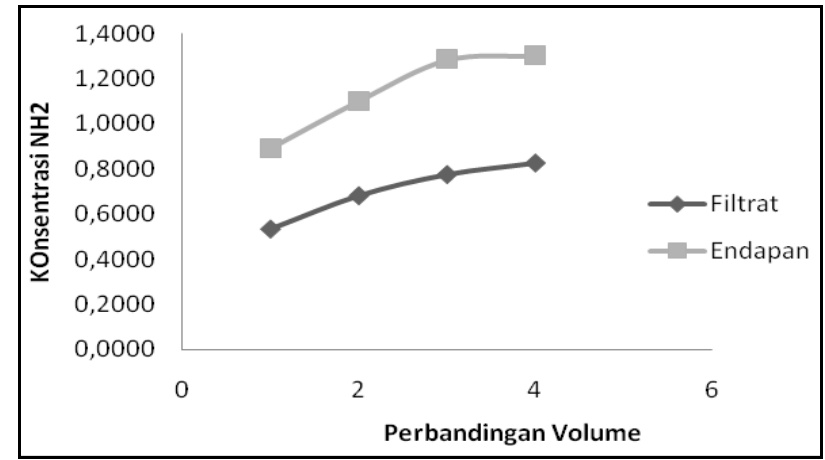

Gambar 3. Konsentrasi amina hasil hidrolisis pada berbagai variasi perbandingan volume $\mathrm{HCl}$

Semakin banyak gugus amina yang dihasilkan maka menandakan bahwa proses hidrolisis berlangsung dengan baik dan asam amino dari hasil penguraian protein semakin banyak pula. Hasil ini belum mencapai optimum dan kemungkinan gugus ini bisa bertambah konsentrasinya bila menggunakan $\mathrm{HCl}$ dengan volume yang lebih banyak. Sementara itu untuk variabel waktu hidrolisis, hasil analisisnya ialah sebagai berikut:

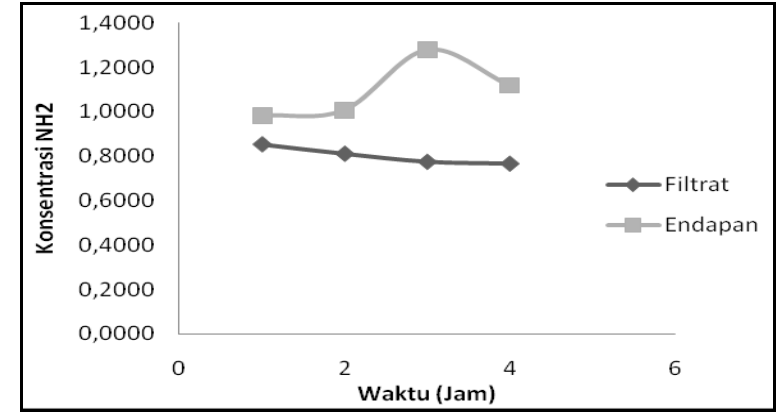

Gambar 4. Konsentrasi amina hasil hidrolisis pada berbagai variasi waktu hidrolisis

Dari Gambar 4 dapat dilihat bahwa konsentrasi gugus amina pada filtrat cenderung mengalami penurunan. Hal ini kemungkinan karena beberapa gugus amina hasil pemutusan ikatan amida diikat oleh anion $\mathrm{Cl}^{-}$. Akibatnya, gugus amina yang terikat pada alkil di dalam filtrat akan semakin berkurang. kecenderungan ini berbanding terbalik dengan konsentrasi amina yang terdapat pada endapan hidrolisat. Pada fase ini, gugus amina cenderung mengalami peningkatan. Adanya peningkatan konsentrasi menandakan bahwa kemungkinan besar asam dengan gugus amina terbanyak terdapat pada endapan dan bukan pada filtrat. Waktu hidrolisis yang optimum untuk mendapatkan amina dengan gugus terbanyak adalah 2 jam. Pada waktu ini, amina yang didapatkan cukup banyak yaitu sekitar 1,2797 mgek/gram. Namun, konsentrasi ini lebih rendah dari hasil analisis amina pada vinasse awal. Pada vinasse, konsentrasi gugus amina yang teranalisis sebesar 4,3918 mgek/gram. Namun hasil ini diperkirakan masih merupakan gugus amina yang terikat pada gugus karbonil atau lebih tepatnya adalah amida dan bukan senyawa amina. Banyaknya gugus amina pada endapan merupakan pertanda besar bahwa asam-asam amino yang terdapat di endapan kebanyakan berupa asam-asam amino dengan gugus amina terbanyak seperti Asam Lysine, Asam Arginine dan Asam Histidine.

Analisis gugus $\mathrm{OH}$ dilakukan sesuai dengan prosedur yang terdapat dalam AOAC [9]. Hasil analisis gugus $\mathrm{OH}$ menunjukkan bahwa asam organik pada limbah vinasse yang dihasilkan dari PS Madukismo hanya mengandung sedikit gugus hidroksil atau dengan kata lain dapat dikatakan bahwa kandungan Asam Laktat, Asam Malic, Asam Sitrat, Asam Threonin, Asam Serine, atau Asam Tyrosine pada limbah vinasse hanya ada dalam jumlah yang sedikit. Hampir semua perbandingan menunjukkan hasil yang negatif dan hanya perbandingan 1:2 yang bernilai positif yaitu sekitar 0,7596 mgek/gram. Hasil ini menunjukkan bahwa keenam asam tersebut hanya dapat dihasilkan bila volume $\mathrm{HCl}$ sebanyak 2 kali dari volume limbah vinasse 
yang akan dihidrolisis. Analisis FTIR hanya dilakukan pada sample endapan hasil hidrolisis dengan perbandingan volume 1:3 dengan waktu hidrolisis 2 jam. Hasil analisis disajikan pada Gambar 5.

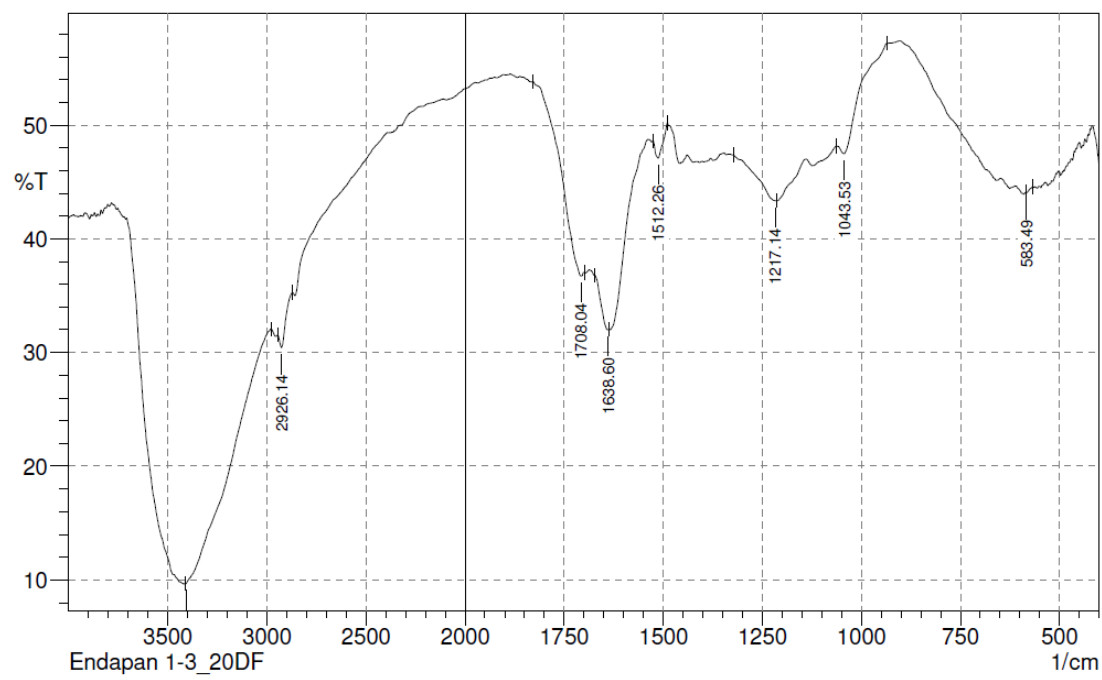

Gambar 5. Analisis gugus fungsi pada endapan hidrolisat

Gambar 5 telah menunjukkan adanya puncak-puncak dari gugus karboksilat, dan amina pada endapan hidrolisat. Dengan adanya hidrolisis, diperkirakan telah terbentuk senyawa asam-asam organik, baik yang mengandung gugus amina ataupun tidak. Gugus karboksil ditunjukkan oleh puncak 1708,04 $\mathrm{cm}^{-1}, 1512,26$ $\mathrm{cm}^{-1}, 1217,14 \mathrm{~cm}^{-1}$ dan $3409,33 \mathrm{~cm}^{-1}$. Puncak-puncak tersebut merupakan ciri khas dari gugus karboksil dengan masing-masing ikatan penyusunnya. Puncak $1708,04 \mathrm{~cm}^{-1}$ merupakan daerah serapan untuk ikatan karbonil $(\mathrm{C}=\mathrm{O})$ pada gugus karboksil. Puncak 1512,26 $\mathrm{cm}^{-1}$ merupakan ikatan $\mathrm{C}-\mathrm{O}-\mathrm{H}$ pada karboksil. Adanya ikatan C-O-H ini diperkuat oleh puncak $1217,14 \mathrm{~cm}^{-1}$ yang diperkirakan merupakan puncak gabungan antara ikatan $\mathrm{C}-\mathrm{O}$ pada karboksil dengan puncak $\mathrm{C}-\mathrm{N}$ pada amina. Selain itu, bukti adanya gugus karboksil ini juga diperkuat oleh puncak $3409,33 \mathrm{~cm}^{-1}$ yang merupakan daerah serapan untuk ikatan $\mathrm{O}-\mathrm{H}$ pada karboksil. Selain gugus karboksil, diduga pada endapan juga terdapat gugus amina. Bila dilihat dari hasil analisis FTIRnya, diperkirakan amina yang terdapat pada endapan hasil hidrolisis vinasse merupakan gabungan dari amina primer dan amina sekunder. Ini dapat diprediksi dari munculnya puncak $1638,60 \mathrm{~cm}^{-1}$ yang merupakan serapan ikatan N-H untuk amina primer dan puncak 1512,26 cm-1 untuk ikatan N-H pada amina sekunder. Hal ini sesuai dengan teori yang ada bahwa ciri khusus dari amina sekunder dan amina primer terletak pada daerah serapan N-H bending-nya. Pada amina primer, daerah serapan N-H bending terletak pada daerah sekitar $1640-1580 \mathrm{~cm}^{-1}$, sedangkan pada amina sekunder terletak pada daerah serapan sekitar $1500 \mathrm{~cm}^{-1}$. Adanya gugus amina ini juga diperkuat oleh puncak $1217,14 \mathrm{~cm}^{-1}$ dan puncak $3409,33 \mathrm{~cm}^{-1}$. Puncak $1217,14 \mathrm{~cm}^{-1}$ adalah puncak C-N yang terdapat di antara ikatan N-H dengan suatu alkil pada gugus amina. Sementara puncak 3409,33 $\mathrm{cm}^{-1}$ adalah puncak untuk serapan ikatan N-H stretch pada amina primer maupun sekunder. Silverstein [10] menyebutkan bahwa ikatan N-H stretch amina akan muncul pada puncak 3500-3300 $\mathrm{cm}^{-1}$ dengan intensitas serapan lemah. Pembeda ikatan N-H stretch pada amina sekunder dan primer terletak pada jumlah band yang muncul. Bila 2 band berarti N-H dari amina primer, sementara bila hanya 1 maka milik dari amina sekunder. Namun pada hasil analisis ini, band dari ikatan $\mathrm{N}-\mathrm{H}$ stretch amina tidak terlihat karena kemungkinan terjadi penggabungan dengan ikatan $\mathrm{O}-\mathrm{H}$ dari karboksil yang memiliki daerah serapan yang berdekatan. Puncak gabungan ini cukup melebar, sehingga dapat memperkuat alasan mengenai adanya gugus amina dan karboksil pada asam-asam organik yang dihasilkan. dari hasil ini dapat disimpulkan bahwa amina sekunder kemungkinan besar terdapat pada endapan hidrolisat dan bukan pada filtrat, mengingat asam-asam amino yang memiliki gugus amina sekunder seperti asam Hidtidine, Proline dan Arginine memiliki berat molekul yang cukup besar sehingga lebih mudah mengendap setelah melalui proses hidrolisis.

Sifat mekanis dari suatu material erat kaitannya dengan sifat kimia yang dimilikinya. Sifat kimia (dalam hal ini ikatan kimia) pada senyawa organik terbentuk dari ikatan antar gugus-gugus fungsi senyawa-senyawa penyusunnya. Oleh karena itu, komposisi gugus menjadi hal yang sangat penting. Paling tidak, gugus-gugus yang akan berikatan tersebut memiliki konsentrasi yang sama banyaknya. Modifikasi pengikatan gugusgugus dari senyawa penyusun polimer yang sering diaplikasikan sebagai coating seperti ester dan amina dapat dijadikan sebagai alternatif dalam menciptakan material coating yang ramah lingkungan dengan sifat- 
sifat mekanis yang unggul. Sebagaimana pula yang pernah dikemukakan oleh Ermawati dan Atmaja [11] bahwa penambahan poliamin dapat memperbanyak terbentuknya ikat silang dalam polipaduannya sebagai pelapis karena sifat mekanis, ketahanan termal dan ketahanan kimianya yang baik.

\section{Kesimpulan}

Dari penelitian yang telah dilakukan, dapat disimpulkan bahwa limbah vinasse dari hasil pengolahan Pabrik Spiritus (PS) Madukismo memiliki potensi untuk dijadikan sebagai material coating. Sebelum sintesis, vinasse dapat dihidrolisis terlebih dahulu untuk membentuk beberapa asam organik. Hidrolisis dapat dilakukan dalam suasana asam dengan kondisi optimum yaitu suhu $100{ }^{\circ} \mathrm{C}$, tekanan 1 atm, perbandingan volume 1:3 dengan waktu hidrolisis selama 2 jam. Hasil penelitian menunjukkan tidak adanya gugus hidroksil pada asam organik vinasse, sedangkan dari hasil FTIR menunjukkan bahwa pada endapan terdapat banyak gugus karboksil dan juga gugus-gugus amina (primer maupun sekunder). Perbandingan gugus karboksil dan gugus amina pada vinasse yaitu sebesar 6,8056 mgek/gram: 1,2979 mgek/gram.

\section{Ucapan Terimakasih}

Penulis mengucapkan terima kasih kepada Kopertis V Yogyakarta yang telah membiayai penelitian ini melalui Program Hibah Dana Penelitian DIPA Tahun 2016, kepada seluruh karyawan dan segenap pimpinan PS Madukismo dan kepada Program Studi Teknik Kimia, Politeknik LPP Yogyakarta.

\section{Daftar Pustaka}

[1] -, 2008. Pemanfaatan Produk Samping Pabrik Gula dan Etanol Menjadi Pupuk Organik Bernilai Ekonomi Tinggi. www.beritabumi.or.id, 28 Februari 2016

[2] Trisakti, B., Silitonga, Y., dan Irvan. 2015. Pembuatan Bioetanol dari Tepung Ampas Tebu Melalui Proses Hidrolisis Termal dan Fermentasi serta Recycle Vinasse (Pengaruh Konsentrasi Tepung Ampas Tebu, Suhu dan Waktu Hidrolisis), Jurnal Teknik Kimia USU, 4(3) :17-22.

[3] Garcia-Depraect, O., Gomez-Romero, J., Leon-Becerril, E., and Lopez-Lopez, A. 2016. A novel biohydrogen production process:Co-digestion of vinasse and Nejayote as complexraw substrates using a robust inoculum, International Journal of Hydrogen Energy. 1-12

[4] Janke, L., Leite , A.F., Batista, K., Silva , W., Nikolausz, M., Michael Nelles, M., and Stinner,W. 2016. Enhancing biogas production from vinasse in sugarcane biorefineries: Effects of urea and trace elements supplementation on process performance and stability, 217:10-20

[5] Fricke, A, R. 2015. Synthetic Resin Composition Comprising Vinasse. U.S. Patent.

[6] Fessenden, Fessenden. 1986. Kimia Organik. Edisi Ketiga. Erlangga, Jakarta.

[7] Parnaudeau V, Condom N, Oliver R, Cazevieille P, Recous S. 2007. Vinasse Organic Matter Quality and Mineralization Potential as Influenced by Raw Material, Fermentation and Concentration Processes. Biosource Technology, 99(2008): 1553-1562.

[8] D'Mello and Devendra C. 1995. Tropical Legumes in Animal Nutrition. Wallingford UK: CAB International.

[9] AOAC. 2001. Protein (Crude) in Animal Feed, Forage (Plant Tissue), Grain and Oil Seed. J. AOAC.Int.

[10] Silverstein, R.M., Bassler, G.C and Morrill, T.C. 1974. Spectrometric Identification of organic Compounds. $3^{\text {rd }}$. John Wiley \& Sons, New York.

[11] Ermawati, S dan Atmaja L. 2013. Pengaruh Variasi Komposisi Hibrid Epoksi-Nilon dengan Poliamin Terhadap Kualitas Sifat Mekaniknya sebagai Pelapis Kayu. Jurnal Sains dan Seni POMITS 1-6. 